原

\title{
直腸切断術後の会陰創一期的縫合閉鎖の検討
}

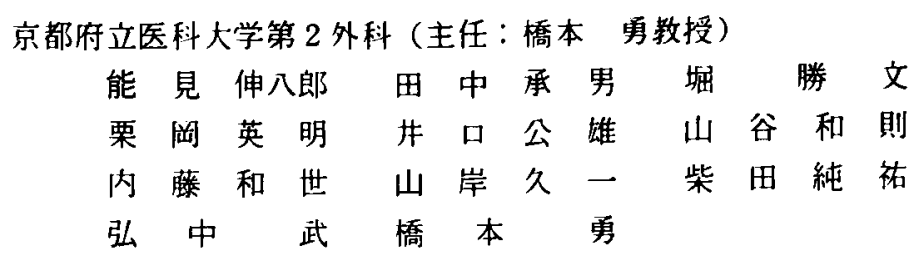

\section{A STUDY OF SURGICAL MANAGEMENT OF PERINEAL WOUND AFTER AMPUTATIO RECTI}

Shinhachiro NOMI, Tsuguo TANAKA, Katsufumi HORI, Hideaki KURIOKA, Kimio IGUCHI, Kazunori YAMAYA, Kazuyo NAITO, Hisakazu YAMAGISHI, Junsuke SHIBATA, Takeshi HIRONAKA and Isamu HASHIMOTO Second Department of Surgery, Kyoto Prefectural University of Medicine (Director: Prof. Isamu HASHIMOTO)

直腸切断術後の会陰㓣は，今日では一期的縫合閉鎖が一般的術式になっている。著者ら は教室で䅅験した97例の直腸癌症例を，切断術後の会陰創をガーゼタンポナーデにて開放 創とした症例，一期的繾合閉鎖しドレナーシ，又はポーティナーによるドレナージを追加 した症例に分類し，会陰創の治寉について検討した，さらに会陰創治虑に影響を与えると 考えられる要因についてす若千の倹討を加えた。

その結果, 直腸切断術後会陰創の早期治虑をはかるには，一期的縫合閉鎖が不可欠であ り, 創感染により創治痣が遷延しても開放創とほぼ同じ日数で創治疬がはかれた. Rb 症例

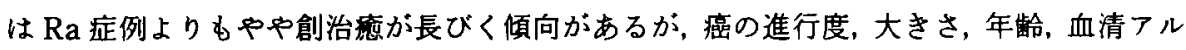
ブミン值怙よび術後早期からの癌化学療法には影響を受けなかった。

(1)はじめに

直腸切断術後の会陰創の一期的縫合閉鎖は, 創治空 を短縮し，術後の苦痛軽減のみならず，早期離床によ る術後合併症の予防にも非常に有効であり，今日では 一般に広く行なわれている(1) . 著者らも現在では会 陰創の一期的縫合閉鎖をルーチンに行なっているか， 過去15年間の直腸癌手術97例をみると，過去の切断術 後ガーゼタンボナーデを行い開放創とした年代と現在 の上らな一期的縫合閉鎖+ドレナーシ又はボーティ ナーによる吸引を追加した年代に大別される。これら の症例のらち会陰創の一期的释合閉鎖を行なったもの そ開放創としたものについて，その創治瘜に要する日 数の比較検討を行なった．さらに会陰創の治瘾に影響 を与えるのではないかと考えられた要因についても検
討を加え若干の知見を得たので報告する.

\section{(2) 研究対象}

昭和 42 年より昭和 56 年の 15 年間に教室で経験した直 腸癌は97例であり，年路は23歳より84歳に抢よび，平 均年齢は58.4 \pm 14.0 歳 (平均 $\pm \mathrm{SE}$ ), 性別では男62例 (63.9\%)，女35例（36.1\%）であった。切除率は88例 $90.7 \%$ ありり，術式は低位前方切除16例 (16.5\%), pull-through 法 4 例 (4.1\%), 切断術65例 (67.0\%), 人工肛門造設術10例（10.3\%）であった。今回は直腸 切断術が施行された65例を対象に，会陰創の治癁日数 について検討を加えた。な敃治虑日数は，手術後のド レーン抜去のあとを含めて，ガーゼ交換が不要となっ た日までとした。

直腸切断術に際し会陰創の皮㾰切開は、尾骨の先端, 
両側万は坐骨結節の約 $1 \mathrm{~cm}$ 内側, 腹側は会陰の中央 部を目安とし，肛門挙筋を坐骨直近で切断している。 切断術後会陰創の一期的䋖合閉鎖時には，左右より対 称にゴムドレーンのみ，あるいは左右よりゴムドレー ン及びポーティナーを対称に挿入し，ボーティナー使 用時はゴムドレーンを絧系で結禁し空気の吸引を止め ている. 術後 1〜2日目にポーティナーを抜去しゴム ドレーンのみとするが，ドレーンの平均插入期間は $11.5 \pm 1.3$ 日 (平均 $\pm \mathrm{SE}$ ) である。また骨盤腹膜は，可 能な場合には原則として縫合しており，会陰創はナイ ロン糸にて皮用のみ繾合閉鎖し，ほぼ 2 週間目に抜糸 している.

\section{（3）成 績}

a) 福の占居部位よりみた会陰㓣の治痹日数

直腸切断術が施行された癌の占居部位は，Rs 10例,

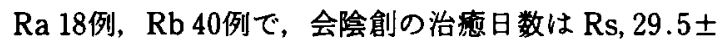
9.0日, $\mathrm{Ra} 45.4 \pm 5.3$ 日, $\mathrm{Rb}: 55.4 \pm 4.2$ 日 (平均 $\pm \mathrm{SE}$ ) で，占居部位が下方になるほど会陰創の治虑日数が長 びく傾向があるが，統計学上の有意差はみられない。 次に表 1 の如く，Ra, Rb 症例についてて，5年間ずっ 3 期に分けて，会陰創の治癦日をみると，昭和42年より 46 年までは，昭和 47 年より51年に比較して治痔日数が 短いがこれは創の完全治瘾を待たずに退院する症例 が多かったため，真の完全創治虑の時期が不明な例が 多く，便宜上退院日を創治窟日とした結果である．全 症例に創の一期的䋖合を行なら様になった，昭和52年 より56年は，昭和47年より51年と比較して, $\mathrm{Ra}, \mathrm{Rb}$ 症 例ともに治痨日数が短く, Rbに拈いては $\mathrm{p}<0.05$ の有 意差を示した。

\section{b) 瘦の進行度及び大きさと会陰創治㦄日数}

直腸癌の stage と会陰創の治恣日数を検討すると， 表 2 に示したように, stage I 53.1士8.1日, stage II

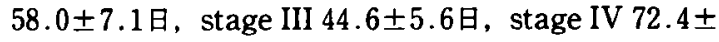

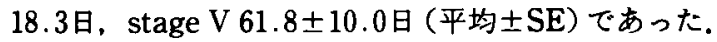
stage が進行する程, 会陰創の治瘾日数が長びく傾向 がずかにみられるが，統計学上の有意差はみられな

\section{表 1 占居部位別会陰創治㦄日数の变遷}

\begin{tabular}{c|c|c|c|} 
占居部位 & 1967 年 1971 年 & 1972 年 1976年 & 1977 年 1981年 \\
\hline$R a$ & $45.6 \pm 7.9(n=5)$ & $59.9 \pm 8.4(n=10)$ & $36.0 \pm 7.6(n=3)$ \\
Rb & $48.1 \pm 9.2(n=7)$ & $65.6 \pm 5.0(n=19)$ & $45.2 \pm 7 . \dot{9}(n=14)$ \\
\hline
\end{tabular}

表 2 Stage 別にみた会陰創治日数

\begin{tabular}{c|c} 
Stage & 治症日数 (mean \pm SE $)$ \\
\hline I & $53.1 \pm 8.1$ \\
II & $58.0 \pm 7.1$ \\
II & $44.6 \pm 5.6$ \\
IV & $72.4 \pm 18.3$ \\
V & $61.8 \pm 10.0$ \\
\hline
\end{tabular}

表 3 直腸满の腫理径（長径）と会陰創治㾀日数

\begin{tabular}{|c|c|}
\hline 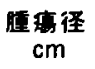 & $\begin{array}{l}\text { 会陰㓣治在日数 } \\
\text { mean } \pm \mathrm{SE}\end{array}$ \\
\hline$\sim 2$ & $43.0 \pm 7.5$ \\
\hline$\sim 4$ & $54.4 \pm 9.1$ \\
\hline$\sim 6$ & $58.1 \pm 5.5$ \\
\hline$\sim 8$ & $48.6 \pm 7.7$ \\
\hline$\sim 10$ & $52.0 \pm 18.7$ \\
\hline $10 \sim$ & $42.5 \pm 1.5$ \\
\hline
\end{tabular}

かった。

腫瘍の長径と直腸切断術後の会陰創治瘡日数をみた が, 表 3 に示したように，腫瘍の大きさと治痣日数の 間には一定の関係はみられなかった。

\section{c）年龄別にみた会陰創の治索日数}

直腸切断術が行なわれた症例を，50歳以下，51歳よ り70歳まで,および71歳以上の 3 群に分けて検討した。 平均治痹は50歳以下 $62.2 \pm 8.4$ 日, 51歳より70歳まて $52.3 \pm 4.5$ 日，そして71歳以上 $60.6 \pm 11.7$ 日平均士 SE)であり，年龄による一定の傾向はみられなかった。 （表 4 ）. また会陰創の一期的䋖合閉鎖群，タンポナー デ群ともに年龄との間に一定の傾向はみられず，年齢 による治蕧日数の差はみられなかった。

\section{d）会陰創処筧別にみた治空日数}

会陰創の処置は，ガーゼタンポナーデ群，一期的縫 合十ドレナージ群, 一期的释合十ボーティナー群の3

表 4 年龄と直腸切断術啳の会隍創治痹日数

\begin{tabular}{|c|c|c|c|}
\hline \multirow{2}{*}{ 会陵烃酉 } & \multicolumn{2}{|c|}{ 会釗治要日数 } & $\operatorname{cen} \pm S E$ \\
\hline & $-50 屯$ & $51 ォ \sim 70 才$ & $71 \neq \sim$ \\
\hline タンボナー君群 & $68.0 \pm 14.4$ & $62.3 \pm 5.2$ & $109.0 \pm 29.0^{*}$ \\
\hline 一期的桻合群 & $57.1 \pm 10.2$ & $46.7 \pm 6.1$ & $46.7 \pm 7.2$ \\
\hline 計 & $62.2 \pm 8.4$ & $52.3 \pm 4.5$ & $60.6 \pm 11.7$ \\
\hline
\end{tabular}




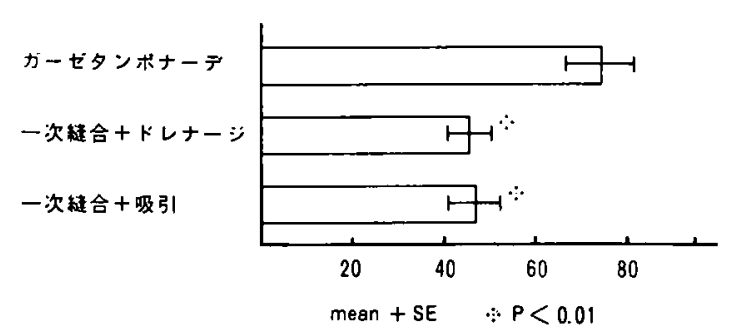

図 1 直腸切断術後の会陰操作と創治痹日数

つに大別される，図1に示すように会陰創治疬に要す る日数は,ガーゼタンポナーデ群74.4

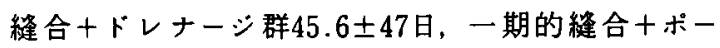

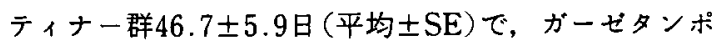
ナーデ群と一期的縫合群の間に，有意な治疾日数の短 縮がみられ $(p<0.05)$ ，一期的縫合閉鎖の有用性が示 されるが，吸引と，単なるドレナージでは治等日数に 差はなく，ボーティナーによる吸引は必ずしも有効と は言えない。ガーゼタンポナーデにより，二次的に創 治瘾をはかららとする場合，腹仙骨式直腸切断術にお いては，創治虑が扔くれる傾向がみられた。 また一期 的縫合十ポーティナー群は，細菌感染がなければ $32.7 \pm 3.4$ (平均 \pm SE) と治瘦日数は短く，2 週で完全 治撚する例がみられるのに対して，細菌感染例の会陰

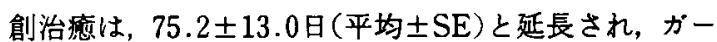
ゼタンポナーデ群と差が全くみられない，一期縫合例 の33\%に細菌感染がみられ，感染の起炎菌は E.coli， Klebsiella Pneumoniae, Pseudomonas Aeruginosa で，66.7\%が占められていた。

\section{e) 術後早期の㾝化学療法との関係}

著者らは術後の癌補助化学療法として, 術後 2 週間 以内に1/2MFC (MMC $2 \mathrm{mg}: \mathrm{CA} 20 \mathrm{mg} 2$ 回/週, FT $207400 \mathrm{mg}$ /日，1クール20日間）を開始しここれ に続いてFT $207600 \mathrm{mg} /$ 日を長期に経口投与してい る.表 5 のよ5に, $\mathrm{Rb}$ で腹会陰式直腸切断術後, 会陰 創を一期的稌合閉鎖した症例では，その創治瘾日数は， 癌化学療法のありなしで全く差がみられず，タンポ ナーデ群では，化学療法をしたものにむしろ治㦄日数 の短縮がみられた。 またガーゼタンポナーデ群と一期 縫合群を合わせた治瘾平均日数は，化学療法群50.9土 5.6日，化学療法をしなかった群60.6士6.1日（平均士 $\mathrm{SE})$ と有意差をみなかった。従って術後早期からの癌 化学㙩法に上る影響はないと考帛られる。

f）血清アルフミン值と会陰創治㦄日数

直腸切断術が行なわれた症例の術前血清アルブミン
表 $5 \mathrm{Rb}$ 症例における腈会除式直腸切断術後の化学 療法と会陰創治痹日数

\begin{tabular}{|c|c|c|}
\hline \multirow{2}{*}{ 会䧔処青 } & \multicolumn{2}{|c|}{ 会䧔剑治西日数 mean \pm SE } \\
\hline & 化学法法あり & 化学㞠法なし \\
\hline タンポナーデ群 & $57.2 \pm 9.3$ & $88.8 \pm 15.6 *$ \\
\hline 一期的艇合群 & $47.5 \pm 8.1$ & $47.6 \pm 6.6$ \\
\hline st & $50.9 \pm 5.6$ & $60.6 \pm 6.1$ \\
\hline
\end{tabular}

\section{表 6 術前血清アルブミン值と直腸切断術後の会陰創} 治瘾日数

\begin{tabular}{|c|c|c|}
\hline \multirow{2}{*}{ 血清フルブミン } & \multicolumn{2}{|c|}{ 会㬝創治瘜日数 mean $\pm \mathrm{SE}$} \\
\hline & タンボナーテ群 & 一期的䋖合群 \\
\hline$\sim 3.0$ & & 49 ( 1 例のみ) \\
\hline $3.1 \sim 4.0$ & $79.6 \pm 10.9$ & $45.3 \pm 4.2$ \\
\hline $4.1 \sim$ & $68.3 \pm 8.9$ & $52.2 \pm 9.2$ \\
\hline
\end{tabular}

値をみると，症例のはとんどが $3 \mathrm{~g} / \mathrm{dl}$ 以上と良好であ $\eta, 4 \mathrm{~g} / \mathrm{dl}$ 以下の症例と $4.1 \mathrm{~g} / \mathrm{dl}$ 以上の症例に分けて 治痹日数を検討した。会陰創一期的繾合閉鎖群では 4 $\mathrm{g} / \mathrm{dl}$ 以下 $45.3 \pm 4.2$ 日， $4.1 \mathrm{~g} / \mathrm{dl}$ 以上 $52.2 \pm 9.2$ 日（平 均土SE）と有意差をみとめず，ガーゼタンポナーデに より開放創とした群でも， $4 \mathrm{~g} / \mathrm{dl}$ 以下 $79.6 \pm 10.9$ 日, $4.1 \mathrm{~g} / \mathrm{dl}$ 以上 $68.3 \pm 8.9$ 日 (平均 $\pm \mathrm{SE}$ ) であり, 統計学 上の有意差をみなかっ（表 6 ）。

\section{g）術後の排尿障害の検討}

術後 7 日以上，バルーンカテーテルを抜去出来な

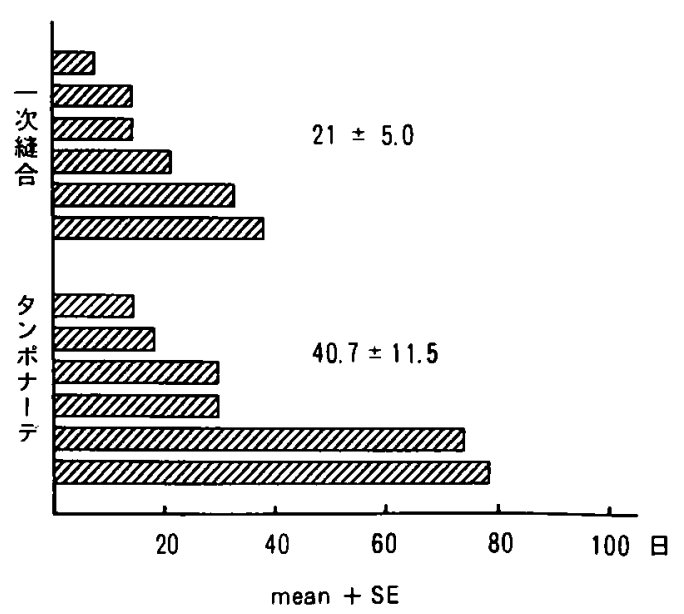

図 2 Rb 症例なおける術後排尿障害 
かった症例を，排尿障害ありとすると，Rs症例の $11.1 \%, \mathrm{Ra}$ 症例の $20.8 \%, \mathrm{Rb}$ 症例の $26.8 \%$ に排尿障 害がみられた. $\mathrm{Rb}$ 症例中, 切断術後の創処置と排尿障

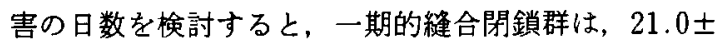
5.0 日に対して，ガーゼタンポナーデ群40.7士11.5日 と，排尿障害が長い傾向がみられた。統計学上の有意 差はみられなかった。ガーゼタンポナーデ群に70日以 上の排尿障害が 2 例みられた（図 2).

\section{(4) 考 察}

直腸切断術後の会陰創は，現在では一期的縫合閉鎖 が一般に行なわれており，開放創に比較し治痖日数の 短縮がはかられている1)-6)，会陰創治庱に影響を与え る因子として，会陰創処置と創感染が最も大きな要因 と考えられる，著者らの検索では，ガーゼタンポナー デにより治療した群の平均治瘏日数は, $74.4 \pm 6.9$ 日に 対して一期的縫合閉鎖した群は平均 $46.7 \pm 5.9$ 日であ ク，さらに一期縫合十ポーティナー群で，感染のみら れなかった症例の平均治瘾日数は, $32.7 \pm 3.4$ 日之非常

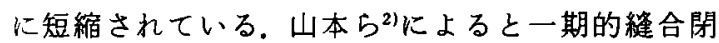
鎖十ポートバック症例13例中10例が， 3 週間以内に会

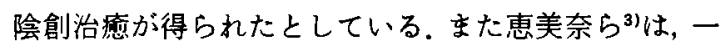
次縫合症例は創感染が少なく，3 月以内に全例治瘾 しているが，開放創としたものは，95\%に創感染がみ られ，56例中 $15 \%$ に 1 年を経ても治瘺しないものがみ られたとし，直腸切断術後の術後感染の减少には，会 陰創の一期的縫合術式はすぐれた方法であるとしてい る。勝見”によると，直腸切断術後の一期的縫合閉鎖の 治瘾日数の平均は, suction drainage を行なったもの 50.9日 (28例), irrigation drainage 例では24.8日 (36 例）とし，後者の有用性を示している。 また会陰創の 合併症の頻度も前者 $67.8 \%$, 後者 $41.6 \%$ と後者の方が 少ないとしている. suction drainage に対する治瘾日 数は，著者らとほぼ同じであるが，著者らはirrigation drainage の経験がなく今後検討したいと考えている. また著者らは骨盤腹膜を可能な場合は原則として繾合 閉鎖しているが，浦ら多によると骨盤腹膜を縫合しな い方が短期間で治誉していると述へてている。

今回の検索では, 一期的縫合閉鎖十ポーティナー群

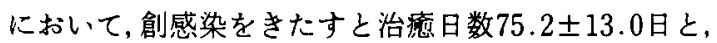
ガーゼタンポナーデ群と同しととなり，一期的縫合閉鎖 は最悪の経過をとっても, 開放創と同一治瘜日数と考 えられる。

直腸癌の部位別に治瘜日数を検討すると, $\mathrm{Ra}$ 症例 に比べ，Rb 症例はやや治瘾日数が長びく傾向がみら
れるが、これは下方に腫瘍がある程，会陰㓣より大き く切除する傾向があったためと考えられる.

さらに会陰創治瘾に影響を与えると考えられる要因 として, 癌の進行度, 患者の年齢, 腫瘍の長径, 血清 フルブミン值との関連について検討したが，これらと 会陰創治痣日数との間に有意の関保はみられなかっ た。また術後早期のFT207を中心とした癌化学療法に も創治瘾が長びくことはなかった。

会陰創の一期的繾合閉鎖術式は，早期社会復帰の面 からもすぐれた方法であるとされるが2，今回の検索 における術後排尿障害においても，ガーゼタンポナー デ群に対して一期的縫合閉鎖群は術後排尿障害の期間 が短い傾向を示した。

\section{（5）結 論}

直腸切断術症例65例をもとに会陰創治㾍に影響を与 えると考えられた要因について検討を加えた，その結 果，会陰創早期治撚をはかるには，一期的縫合閉鎖か 最も効果的であり，感染を生じても，開放創と同じ日 数で創治瘾が得られた，腫瘍が下方にある程創治瘄が 長びく傾向がみられるが, 癌の進行度, 年齢, 尾瘍の 大きさ，血清アルブミン值拉よび癌化学療法による影 響はみられなかった。

\section{文献}

1）暒谷 鐶：大腸癌の外科, 大腸肛門誌, 31 ： 363-370, 1978.

2）山本康久，佐野開三，重本弘定他：直腸癌に対する 腹会陰合併切除一特に会陰創の処置法についての 娭討，大腸肛門誌，30：132，1977。

3）恵美奈実, 岩井昭彦, 宇佐見詞津夫他：直腸切断術 に㧍ける会陰創の一期的縫合閉鎖術式について。 大腸肛門誌，31：495-496，1978.

4）丸田守人, 中黒 孚, 菅谷 宏他: 腹会陰式直腸切 断術の会陰創一期治虑について, 大腸肛門誌, 34 ： 400, 1981.

5）池永 達雄，沢田寿江：直腸切断術・会陰創一期的 释合後合併症について, 大腸肛門誌，34:402, 1981.

6) 土屋周二：直腸癌の手訹, 外科診療, 1197-1200，1975.

7）勝見正治：手術手技研究会記事, 腹腔内ドレナー 二, 手術, $34: 1037,1980$.

8）浦 伸三, 勝見正治, 殿田重彦他：高龄者直腸癌手 術の検討一二期分割腹会陰式直腸切断術一, 日本 臨床外科医学会雑誌, $41 ： 428-433 ， 1980$ 。 